\title{
12. An Economy of Shells: A brief history of La Perouse Aboriginal women's shell-work and its markets, 1880-2010
}

\author{
Maria Nugent
}

Shell-work of the kind made by Aboriginal women at La Perouse in Sydney and in other communities along the NSW coast is not to everyone's taste. Indeed, it has long been described as kitsch or tacky, in part because for much of the twentieth century it was made and sold as a souvenir (Pakula 2007). Some of the most popular shell-work forms are heart-shaped, lidded trinket boxes and ornamental baby shoes (Figure 12.1), as well as the now highly collectible small-scale Sydney Harbour bridges (Figure 12.2). In some respects, La Perouse shell-work sits uneasily alongside other three-dimensional art and craft objects currently made by Aboriginal women in different parts of the country, such as the shell necklaces made by Lola Greeno and others in Tasmania that draw inspiration from pre-contact forms of female body decoration (Kleinert and Neale 2000:496, 698), or the coiled baskets and other fibre work that were recently celebrated in the national touring exhibition ReCoil (West 2007). Unlike these other contemporary art and craft objects, shell-work does not have a clear or certain lineage to 'traditional', pre-contact forms (McKenzie and Stephen 1987:179; although see Vanni 2000:402 for an argument about continuous practices); and there is not the same level of consensus about its aesthetic and artistic qualities among curators, taste-makers, collectors and scholars.

In some cases, La Perouse shell-work has recently become collectible precisely because it is considered kitsch, unusual or quirky (Hart 2003:14-16). For example, in four pieces made by (the late) Lola Ryan between 2000 and 2003, now held by the National Gallery of Australia (NGA), the artist has experimented with applying glitter between the shells in place of the shell-grit that earlier Aboriginal shell-workers typically used; dyed small white shells in bright, lurid colours, such as pink and green, for accent; and favoured fluorescent faux fur as backing instead of the traditional velvet, corduroy or satin (Figure 12.3). As Ryan notes: 'I always like to add a little glitter, that's my mark' (2003:13). These idiosyncratic developments in shell-work design are sometimes the result of collaborations between individual shell-workers and art collectors and curators. In the case of the pieces held by the NGA, the art collector Peter Fay had commissioned them from Lola Ryan for his celebrated collection of eclectic 'outsider art', and had worked collaboratively with her in producing them (Ryan 2003:13). 


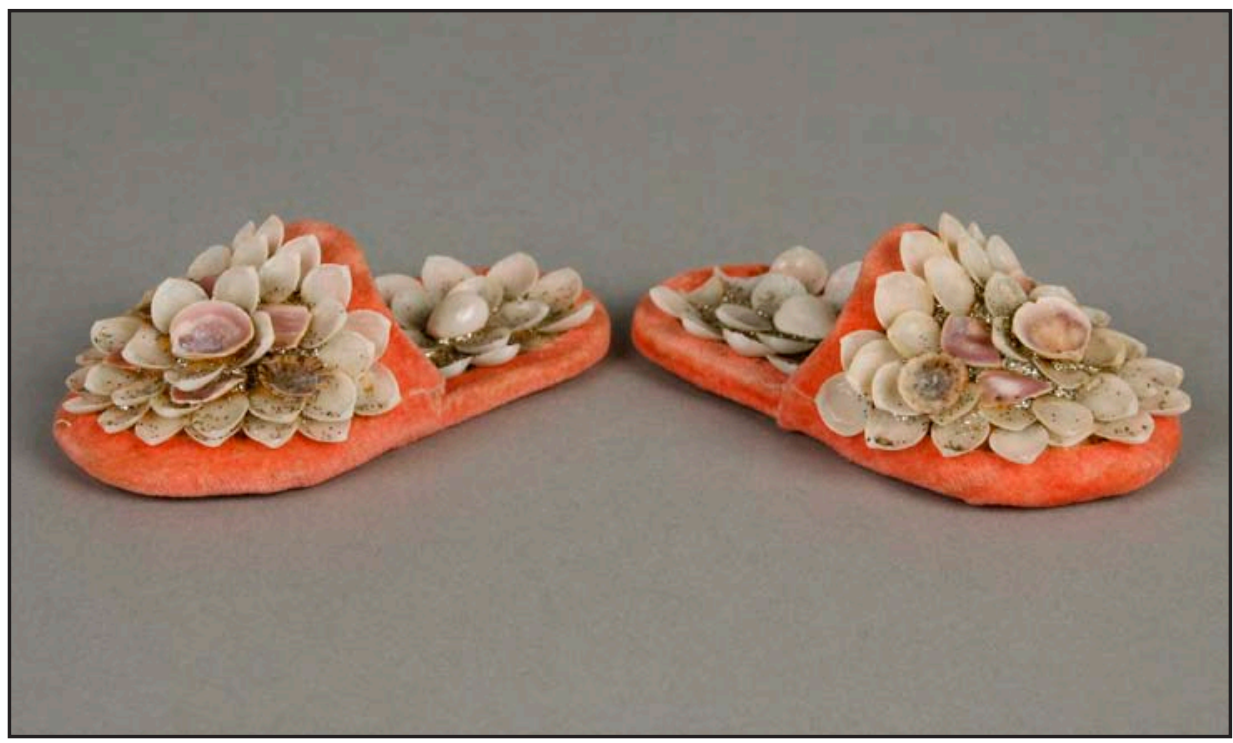

Figure 12.1 Shell-work baby slippers, maker unknown, La Perouse, New South Wales, 1952

Source: Powerhouse Museum, Sydney. Photo: Kristen Clarke.

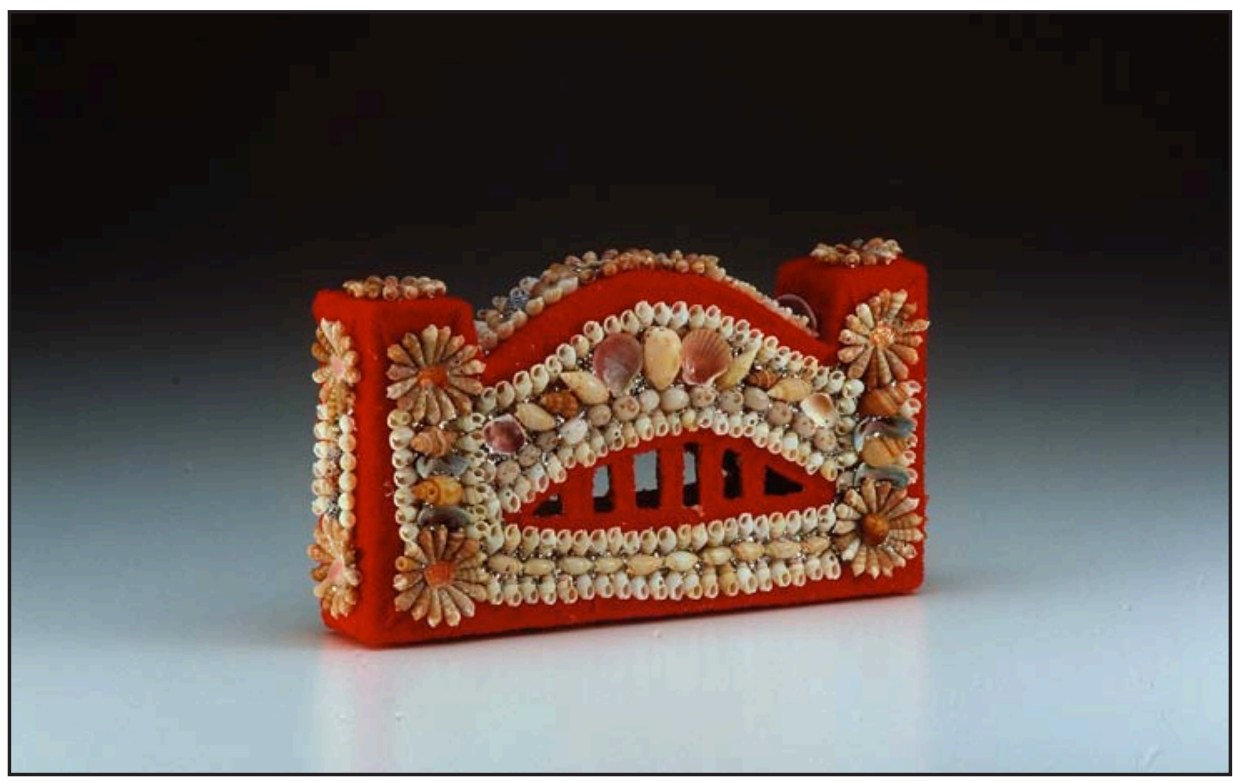

Figure 12.2 Shell-work Sydney Harbour Bridge, made by Mavis Longbottom and Lola Ryan, La Perouse, New South Wales, Australia, 1986

Source: Powerhouse Museum, Sydney. 


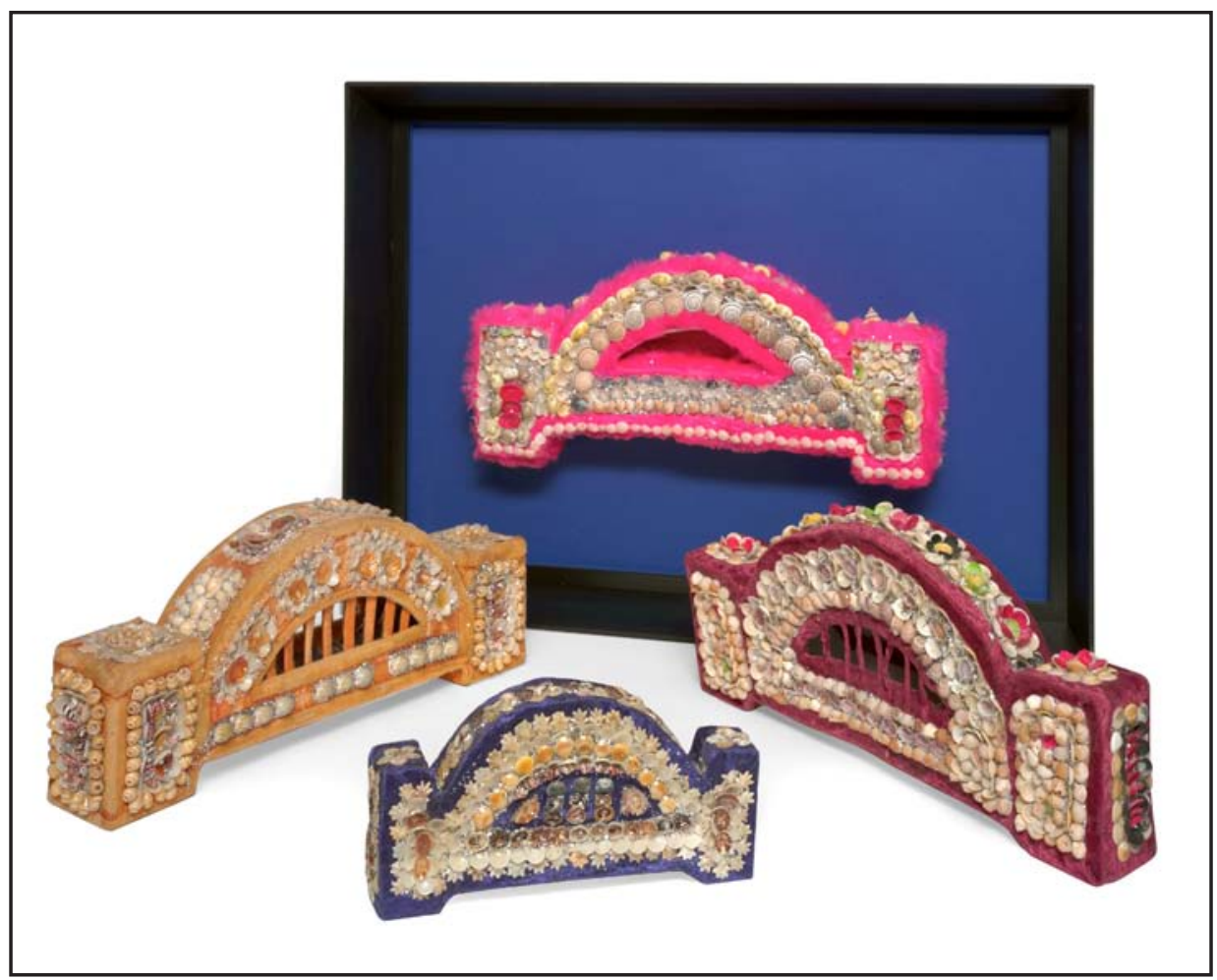

Figure 12.3 Harbour Bridge, made by Lola Ryan, Dharawal/Eora people, La Perouse, New South Wales, Australia, 2000

Source: National Gallery of Australia, Canberra, Gift of Peter Fay 2005.

Not all contemporary pieces of La Perouse shell-work are quite as flamboyant as this. But much of it - particularly if made by one of the few remaining, longpractising shell-workers - has now become highly sought after and has, to some extent, acquired the status of art. As in the case of Lola Ryan's shelled harbour bridges in the NGA, this process has been helped along by art collectors and curators who have included La Perouse Aboriginal women's shell-work in exhibitions of contemporary 'urban' Aboriginal art, acquired it for public and private art collections and entered it into art competitions (Allas 2006:24-6). As though an endorsement of their collective efforts, in 2005 a blue-velvet, shell-encrusted model Sydney Harbour Bridge made by Esme Timbery won the inaugural Parliament of New South Wales Indigenous Art Award (Parliament of New South Wales 2005). Commenting upon this event, Aboriginal art curator Tess Allas claimed that 'no longer were [shell-works] mere souvenirs for tourism consumption...[They are] regarded as art objects worthy of discussion and collection' (Allas 2006:25). 
The complex, and somewhat fraught, relationship between so-called 'tourist art' and 'high art' has been explored thoroughly in histories of Indigenous art in Australia and elsewhere (Finlayson 1990; Graeburn 1976; Morphy 1991; Myers 2002; Phillips 1998; Phillips and Steiner 1999), and it is not my concern to rehearse those arguments here. My more particular interest is in the accrual of new stories about Aboriginal women's shell-work as part of the process by which it is being ascribed anew as art, and especially the ways in which some recent accounts discount its previous value, including its economic value, to the women who made it. The North American art historian and curator Ruth B. Phillips has noted the ways in which the exclusion of tourist art from contemporary scholarly consideration and connoisseurship - disqualified apparently because of its hybrid, inauthentic quality - belies, and threatens to erase, its historical significance. She argues that it is important to study precisely for the evidence the objects themselves provide of 'aboriginal peoples' negotiation of Western artistic and economic systems' (Phillips 1995:99). Other scholars, such as Howard Morphy in Australia, have shown that the relationship between the tourist market and the fine-art market is not quite as distinct or discrete as is often suggested (Morphy 1991:10-38). These contexts are overlapping rather than opposed.

And so, I want to suggest that the situation in which Aboriginal women's shell-work now finds itself cannot be explained quite so simply or as straightforwardly by narratives that emphasise progress and development. A history of Aboriginal women's shell-work production from the late nineteenth century to the present clearly demonstrates that emergent narratives about shell-work's supposed liberation from the tourist market to the art world threatens to obscure more than it promises to reveal. Emphasising the aesthetics of these objects overshadows their earlier, more quotidian qualities, including their economic value to the women who made them. The new celebratory accounts of shell-work's development from tacky souvenir to art object rely upon staging a break between past and present: no longer mere souvenirs for tourist consumption; now artworks worthy of collection and discussion. But even a brief historical survey of shell-work and its markets shows that such a break is largely unsustainable.

This chapter traces some of the markets in which shell-work was sold prior to being embraced by the contemporary Aboriginal art market in Sydney (and other metropolitan centres) at the turn of the twentieth century. The period covered spans about 130 years. A long historical view that takes account of marketplaces, production methods, designs and forms reveals less a picture of discontinuity and disjuncture between what shell-work was and what it is now; rather, what emerges is some striking continuity over time. Throughout the history of its production by Aboriginal women, new, and sometimes surprising, 
markets regularly opened up for these commodities. Considered historically, then, the most recent putative transformation of shell-work into art object can be interpreted as yet one more instance of Aboriginal women's shell-work entering a new marketplace, appealing to a different cohort of consumers and acquiring additional meanings as it does so. Moreover, the ability of the few remaining active producers of shell-work to respond to this latest, unexpected assessment of its value and desirability as collectible art object should not be underestimated. That, too, has historical depth, as I hope to show.

As their shell-work circulated in a variety of marketplaces, Aboriginal women demonstrated an ability and acuity to negotiate 'changes in taste and market' (Phillips and Steiner 1999:9). Ruth B. Phillips and Christopher B. Steiner have argued that the capacity of Indigenous art and craft producers to react to market pressures has not always been recognised adequately in the scholarly literature. While this is no longer a criticism that can be easily levelled at studies of indigenous tourist art in many parts of the world, it remains true of historical studies of Aboriginal women's commodity production in nineteenth and twentieth-century Australia, particularly in the intensely settled southeast. This is borne out by the small, albeit growing, literature on shell-work. More emphasis tends to be given to the ability of Aboriginal women to maintain traditions and preserve knowledge (see Nash 2010; Vanni 2000) and less given to their responsiveness to the fashions and fancies of consumers. This is so despite evidence that across the many decades Aboriginal women have made shellwork, it was regularly modified to cater to the tastes of existing buyers or to appeal to new ones.

The relative absence of attention given to the market context might be due to the fact that most studies of Aboriginal women's shell-work productionor their production of similar kinds of craft objects such as feather flowersin south-eastern Australia have emerged either from community or from arthistorical studies. In those studies, themes of culture and identity are given more emphasis than economics. Indeed, in general terms, the economic value to Aboriginal women of making decorative objects expressly to sell has been little considered in Australian historical scholarship, including that of labour history. In the latter, most attention has been given to the services (rather than the commodities) that Aboriginal women provided in a colonial economy, such as domestic labour or sex (Curthoys and Moore 1995:20-9).

There are some notable exceptions (although few recent ones). Diane Barwick's work on the history of the Coranderrk settlement outside Melbourne is exemplary for revealing that the rush baskets and rugs that Aboriginal women (and some infirm old men) made for sale between the 1860s and 1880s were a vital source of income for the entire community - in some years, more profitable than men's participation in seasonal employment (Barwick 1974). 
Barwick argued that not only was women's commodity production crucial to the settlement's viability in its early phase, but it also contributed to changes in gender relations. She argued that 'a major reason for the male station residents' increased willingness to treat their womenfolk as equals was their new economic importance' (Barwick 1974:54). Moreover, she suggested that this source of income influenced Aboriginal women's consumption patterns, allowing Aboriginal women to purchase 'luxuries' as well as necessities. Art historian Sylvia Kleinert is likewise attentive to the economic value of Aboriginal women's craft production in the early twentieth century in her study of Aboriginal art in south-east Australia (Kleinert 1994). Although her central concern is with art as a means of expression of Aboriginal identity in a colonised context, Kleinert also highlights the ways in which some Aboriginal women were able to use craft production - particularly of objects that white women desired, such as feather flowers and string purses made from water-rat skins - to enable them to live relatively autonomously, if precariously, in fringe camps on the edges of rural towns in Victoria (Kleinert 1994:155-8).

From the archival material available, which is mainly government reports, newspaper articles and missionary records, it is impossible to compile precise quantitative information about shell-work's contribution to the livelihoods of Aboriginal women and their families and communities. Only occasionally are the amounts of money made from the sale of shell-work mentioned. More common are assertions about its contribution to Aboriginal people's subsistence. For example, in a series of letters to the editor in the Sydney Morning Herald between 1902 and 1906, when the NSW Aborigines Protection Board threatened on repeated occasions to relocate the Aboriginal settlement at La Perouse to a more isolated site, the importance of the shell-work trade was repeatedly cited as a reason against the proposed move. Supporters of the La Perouse Aborigines argued that they should be permitted to remain where they were because their location allowed them to participate in a cash economy created by tourists and other visitors, which gave them a degree of economic independence and autonomy. 'For half a century', one letter noted, 'the natives have been allowed to occupy a small piece of land on the northern shore of Botany Bay, where they have established comfortable little homes, and are now able to make a few shillings by the sale of their shell work to visitors' (Sydney Morning Herald, 17 November 1906:17; see also Sydney Morning Herald, 9 November 1906:10). The writer noted anecdotally that 'I know of instances where expensive medicines, and other necessities, have been obtained by the proceeds of this work that would have been absolutely impossible otherwise' (Sydney Morning Herald, 17 November 1906:17). Another noted that 'not a small amount of money is obtained from the sale of shellwork' (Sydney Morning Herald, 13 November 1902:8), but does not quantify that claim. 
While these public statements about shell-work emphasise the economic significance of the trade (and many more like them can be found), it should be noted that there is a plethora of statements preserved in the archival records, as well as within recorded oral histories of shell-workers, that suggest its contribution to Aboriginal women's livelihoods was at other times marginal at best (Nash 2010). Reconciling these conflicting assessments, and determining their respective historical specificity, requires further research. In the meantime, my approach in this chapter is to examine the markets through which these objects circulated at different times. Many markets are mentioned, some briefly, some in more detail, in archival material, particularly missionary records and newspaper reports. In taking this approach, I am influenced by Arjun Appadurai's observation that things have a social life. This 'conceit', as he calls it, helps to focus attention on the ways in which commodities circulated 'in different regimes of value in space and time' (Appadurai 2005:4, emphasis in original) as they moved in and out of markets-local, metropolitan, domestic and international.

The chapter is divided into three sections, each focusing on a distinct market. The first considers early reports that Aboriginal women originally sold their wares in Sydney streets and suburbs. In it, I speculate about the consumers of these commodities. In the second section, I discuss the influence of missionaries based at La Perouse in expanding the markets available to Aboriginal women shell-workers, which included both domestic and international ones. The final section considers the development and consolidation of a local market for these objects as visitors to La Perouse increased. I suggest this provided the conditions for the gradual transformation of shell-work into souvenirs for tourist consumption, which dominated the trade between the 1930s and 1960s. By shadowing shell-work as it moves in and out of these various marketplaces, something is revealed of its economic as well as its cultural, social and aesthetic values across time and place, even as its material form remained constantly recognisable.

\section{Street Selling}

By the opening years of the 1880s, certainly, and probably during the 1870s, if not before, the marketplaces for Aboriginal women's shell-work were the city's public streets and the suburbs' private homes. Reporting to the recently appointed NSW Protector of Aborigines in early 1883, the local policeman, Senior Constable Byrne, whose beat covered La Perouse on Botany Bay, stated that the Aboriginal women and girls living there contributed to the livelihood of their families 'by making shell baskets, which they sell in Sydney and the 
suburbs' (NSW Legislative Council 1883:315). It is one line in a longer report, but nonetheless contains a couple of illuminating details about the shell-work business.

First, it mentions that the objects made at this time were shell baskets. While there are no known surviving examples of shell-work made by La Perouse Aboriginal women from this period, shell baskets are described in many Victorian women's craft pattern books and magazines published about this time as well as in later histories of women's arts and crafts (Cochrane 1992; Isaacs 1987; Toy 1988). Shell baskets are essentially decorative items, perhaps used nominally for holding trinkets or as letter holders, so fit into the category that Ruth B. Phillips, historian of Canadian aboriginal women's art and craft production, refers to as 'tidies' (Phillips 1998:205-8). The Victorian era, she argues, was obsessed with orderliness and neatness, and so was the age of decorative containers.

Second, the policeman's report explains that the outlets for Aboriginal women's shell baskets were the city, where they were presumably sold by hawking them in the streets, and the suburbs, where they were probably sold door-todoor. In the middle to late nineteenth century, Aboriginal people living in and around Sydney survived mainly as mendicants, as Ann Curthoys (1982:32-3) has shown. This was the period, before the establishment of the office of the NSW Aborigines' Protector, in which there was an almost complete absence of organised social support for Aboriginal people, either from the state or from missionaries. In this context, the production and sale or exchange of commodities, such as shell baskets, which appealed to some Sydney residents, constituted a small component of Aboriginal women's precarious means of livelihood.

The policeman's report does not shed any light on who bought these shell baskets, and evidence is sparse on that matter. Nonetheless, some speculations can be made. Women's art and craft magazines from the period regularly included patterns for shell baskets and other ornamental objects (McKenzie and Stephen 1987:179). Jennifer Isaacs in her study of Australian women's domestic and decorative arts notes that it was a popular form of ornamental decoration (Isaacs 1987:166), and a few decorative pieces survive in museum and private collections (Logan 1998:66). Some early photographs of the interiors of Sydney houses reveal shelled items on display, although none that can be identified as having been made by Aboriginal women because their wares were likely to have been indistinguishable from similar objects made by non-Aboriginal women in the same period. Moreover, Isaacs notes that shelled objects, particularly small boxes, were sold commercially in this period, usually in coastal holiday places (Isaacs 1987:167). That there was a local shell-work industry in this period is 
further confirmed by reports that ornamental shell-work was being included in colonial industrial exhibitions, and claims that this contributed to greater demand for it. According to one report published in 1882:

[I]n one of the colonies...the manufacture of ornamental shellwork formed part of its industry, and chiefly of the female industry. This manufacture was carried on to a very limited extent. An industrial exhibition was opened, and prizes were given, amongst other things for the best specimens of this ornamental shellwork...The result was very satisfactory. Orders came in to a very considerable extent from England and elsewhere, and created a great deal of sensation... and remunerative prices followed upon the increased demand - a demand which, I am sure, busied the hands, and I feel confident, lightened the hearts of many a struggling widow and her children. (Mercury, [Hobart], 27 June 1882:3)

Given this, it seems likely that the buyers for shell-work-whether made by Aboriginal women or other producers - were not fashionable Victorian women alone.

Nineteenth-century Sydney was a maritime city, and crews on mercantile ships are another plausible market for shelled objects. In suggesting this, Aboriginal women's shell-work warrants comparison with objects known as 'sailors' valentines' (see Fondas 2002). These were decorative shell mosaics, made of two hexagonal frames hinged together to form a box, which were made by local women in port towns in the Caribbean in the nineteenth century and earlier to sell to crews on visiting ships (Toller 1969:16-18). As Peter Cochrane notes, nineteenth-century Sydney was 'a little port city', with enterprise and activity centred on the wharves (Cochrane 2006:27). Grace Karskens paints a similar picture of Sydney, but one in which Aboriginal people are more visible. She describes Aboriginal men following the comings and goings of ships, working on the wharves or joining crews (Karskens 2009:425-32). The Aboriginal women and girls reported as making shelled objects in the 1880s were familiar with the wharves, especially around Circular Quay. At least some whom the policeman mentioned in his report had lived in the boatsheds there, before being forcibly relocated to La Perouse only a year or so earlier (Nugent 2005:46-7). This gives some sustenance to the idea that they had access to trade, formal or informal, operating around the wharves and boat sheds.

\section{Missionary Markets}

Throughout the closing decade of the nineteenth century and the opening one of the twentieth, the city and suburbs remained a prime marketplace for shellwork, and one in which Aboriginal people sold it to buyers directly. This is 
known to have been the case because when a new policy to make Aboriginal people pay fares on city trams was introduced in 1903, there was some outcry, with one opponent of the scheme writing that ' $[\mathrm{t}]$ he Aboriginal people at La Perouse are in many cases, but half fed and clothed and they are to be still further impoverished by demanding from their already limited incomes (procured in some instances by selling shell-work, etc., in the city) fares for tram tickets' (New South Wales Aborigines Advocate, 30 June 1903:2-3).

The growing inaccessibility of the city's streets to Aboriginal people - a byproduct of government efforts to spatially segregate Aborigines from white society (Goodall 1996:88-9; Nugent 2005:53-7) — allegedly threatened the shellwork business, but the emergence of missionary markets in this period provided some compensation.

Missionaries are a strong presence in the history of the Aboriginal shellwork business. It has been suggested that missionaries and church workers, particularly those who had spent time in the Pacific where shell-work production was common, were responsible for introducing the practice to Aboriginal women in a bid to assist them to become economically independent and industrious (McKenzie and Stephen 1987:179). For instance, in her work on Aboriginal shell-workers Jane and Olive Simms, Ann Stephen argues that ' $[\mathrm{t}]$ he Methodist missionaries [at La Perouse] had formerly worked in Fiji and appear to have seen the potential for adapting South Pacific shellwork locally' (Stephen 1995). As an explanation of the origins of shell-work production among Aboriginal women at La Perouse, it is difficult to endorse this interpretation. The historical records suggest that they were already making shelled objects, such as shell baskets, before missionaries with experience in South Pacific mission fields took up permanent residence at the La Perouse settlement in the early 1890s (Telfer 1939). What is clear, though, is that missionaries were responsible for fostering and encouraging the practice, for providing contexts and conditions for its continuation, and, most importantly, for facilitating access to new markets for it.

In the opening years of the twentieth century, missionary and church outlets began to complement some of the existing markets for shell-work made by Aboriginal women. In addition to becoming part of a gift-giving economy that involved Aboriginal people and missionaries enacting and expressing relationships of obligation and reciprocity, Aboriginal women's shell-work was regularly included in missionary exhibitions, sometimes only for display, but often for sale. Within these contexts, the delicate shelled objects were presented as material evidence of the fruits of the missionaries' labour in encouraging Aboriginal women's assimilation. For instance, in 1903, the same year that the introduction of tram fares jeopardised its sale in Sydney's streets, Aboriginal women's shell-work was included in a display of 'the handiwork of the Aborigines in NSW' in a mission loan exhibition (probably the Church Missionary Society's 
Loan Exhibition) held over a week at the Sydney Town Hall. This displaycarefully choreographed-presented a melange of the material culture of 'traditional' ways of life (such as a 'native gunyah' and wooden implements such as boomerangs and spears) and contemporary manufactures (such as shell baskets) that had been produced under missionary tutelage (New South Wales Aborigines Advocate, 30 June 1903:3). The display, like all such mission displays, was as much about promoting the work of the missionary organisation active in Aboriginal settlements in New South Wales in this period, as it was about exhibiting objects made by Aboriginal men, women and children. A report on the exhibition tellingly captured this ambiguity, noting that the Aborigines' mission was grateful 'for the privilege of bringing under the notice of the public the work of our people' (New South Wales Aborigines Advocate, 30 June 1903:3).

In this same early twentieth-century period, missionaries also provided access to markets much further afield. In 1910, for instance, it was reported that La Perouse shell-work was included in an exhibition of Australian manufactures as part of the Girls Realm Guild Bazaar held in the Royal Opera House at Covent Garden in London (Sydney Morning Herald, 12 January 1910:5). According to one report, 'the Lady Rachel Byng and the Hon. Mrs. Schomberg Byng, were large purchasers, the latter buying the beautiful New Zealand cot blankets, and shell-work from Sydney, made by Queen Emma at the Aboriginal Camp at La Perouse' (Australian Aborigines Advocate, 28 February 1910:4). In this instance, as in many others, the shell-work made by Aboriginal women was included as part of a display of women's work, which also included items made by the white missionary women. The same report praises the 'beautifully designed post cards of Miss M. Oldfield, and the Water Colours of Miss Fry', two church-workers who lived at La Perouse and other Aboriginal settlements in New South Wales (Australian Aborigines Advocate, 28 February 1910:4). This is a quite singular account because it names not only the makers of things, but also the buyers, providing a rare glimpse of at least some consumers of these commodities. In this case, they are sisters-in-law from a prominent English church family, supporters of the Girls Realm Guild (Brewis 2009:765) and connoisseurs of women's domestic arts and crafts. Lady Rachel Byng, for instance, for a time owned an embroidery shop in London.

While Emma Timbery's shell-work was being bought in London, back in Sydney the same year (1910) other shell-work made by Aboriginal women at La Perouse and other parts of New South Wales was on display at the annual Royal Agricultural Show (RAS). There it was included as part of what was known as the Aboriginal Exhibit, which could be found in the Industrial Pavilion, although, as one newspaper article pointed out, 'in a quiet corner of it' (Australian Star, April 1910). In addition to shell-work, the exhibit included 'mats, and articles made by children attending schools on... mission stations' (Australian Aborigines 
Advocate, 31 March 1910:1), as well as 'dilly-bags netted from various materials' (Australian Star, April 1910). Proceeds from the stall were reportedly £30 in total, but it is not clear how this money was distributed to the producers of the items sold. The report in the mission magazine simply noted that 'these exhibits being sold entirely for the benefit of the native people' (Australian Aborigines Advocate, 30 April 1910:6).

As was the case for the exhibition in London, at the RAS, it is clear from reports that Aboriginal women's shell-work was competing with shell-work made by non-Aboriginal people. Describing the La Perouse shell-work displayed at the Aborigines Exhibit, one journalist noted that 'by happy chance there is a stall quite near this one on which the shell work of English workers challenge[s] those of the black men [sic]' (Australian Star, 1910). Using the comparison to underscore his argument that the value of Aboriginal-made shell-work was the evidence it provided of the capacity for 'progress' of the makers of it, the writer claimed that the English-made examples are 'more advanced, for the shells are made up in the most perfect imitation of flowers. But the work of the aborigines is clear evidence of an attempt to cultivate the arts with some imagination, imitation and a sense of beauty - all of which go towards creating the highest culture' (Australian Star, 1910).

It was on aesthetic terms such as this that La Perouse shell-work was increasingly judged in this period, especially when it appeared alongside shell-work made by non-Aboriginal people. The following year, La Perouse women's shell-work (and bead-work) was once more on sale at a Girls Realm Guild bazaar, this time at the Sydney Town Hall (Sydney Morning Herald, 27 April 1911:7), and again it provided the basis upon which claims about the potential for education and improvement of Aboriginal women and girls were made publicly.

\section{Local Traffic}

In ways that overlapped and articulated with markets both near and far, there was always a demand for Aboriginal women's shell-work at La Perouse itself. Some of that trade came from the steady stream of visitors to the Aboriginal mission. According to one, perhaps exaggerated, report: 'Hundreds of people patronize the trams weekly in order to visit the little mission church, and see the results of the works amongst the people' (Sydney Morning Herald, 9 November 1906:10). Those numbers swelled for one week each year (initially in November, afterwards in January), when the mission held its annual convention. Aboriginal women took advantage of the situation by setting up shell-work stalls around the convention site, where they reportedly did 'a brisk trade' (Australian Aborigines Advocate, 30 November 1908:4). 
In this same period, Aboriginal women's shell-work began to circulate in a local tourist market. That market had been growing as La Perouse on Sydney's periphery emerged as a metropolitan tourist site, tied to the city by the tram network (Nugent 2005:70-3). While shell-work's souvenir status is often emphasised in potted histories, relatively little attention is given to the ways in which Aboriginal women adapted their existing practices to cater more explicitly to a tourist market. Initially, the souvenir trade was dominated by Aboriginal men, who turned 'traditional' wooden objects into tourist objects by decorating them with iconography that would appeal to tourists and by performing the use of them (see McKenzie and Stephen 1987:179-81; Nugent 2005:79-83; Vanni 2000:400-2). Only gradually did Aboriginal women's shellwork come to be identified as a souvenir like the decorated boomerangs. That transformation happened by Aboriginal women making shelled objects in ways that borrowed from the iconography that Aboriginal men used on the wooden souvenirs that they made. For instance, while Aboriginal women continued to produce heart-shaped boxes, which reportedly remained the most popular line (Longbottom and Ryan 1986), decorative shelled objects in the shapes of maps of Australia and Sydney Harbour bridges, which were designs used to adorn tourist boomerangs, began to be produced (Figure 12.4). This development begins to occur from about the late 1920s and early 1930s onwards.

It seems that Aboriginal women were assisted by their male relatives in this process of turning shell-work into souvenirs. According to two sisters who were active shell-workers in the 1940s and 1950s: 'We had a father who was very clever at drawing things and you know, he used to do all the patterns for us' (Longbottom and Ryan 1986). This is suggestive of the ways in which the production of shell-work gradually came to take place within the context of Aboriginal families, with Aboriginal men and Aboriginal women as well as children working together. This mode of production contrasts with the earlier period, in which Aboriginal women and white women worked together to make shelled objects as feminine, domestic crafts rather than as souvenirs. Indeed, I want to suggest that critical to this development in the social life of shell-work, both in its production and in its sale, was the rise of individual Aboriginal family-owned souvenir businesses, such as the one operated by Joe Timbery and his family, which is a topic requiring further investigation and analysis. Moreover, whereas missionaries had previously occupied the role of 'agents', buyers increasingly assumed this function in getting shell-work into circulation, working on behalf of metropolitan department stores. As Gloria Ardler noted: 'My dad and mum and aunty had a little business going with their shellwork and boomerangs. They sold them to David Jones and sent work to Melbourne and even overseas' (Ardler 1988:39). Just as commonly, shop owners in the city bought stock directly from the makers (Longbottom and Ryan 1986). 


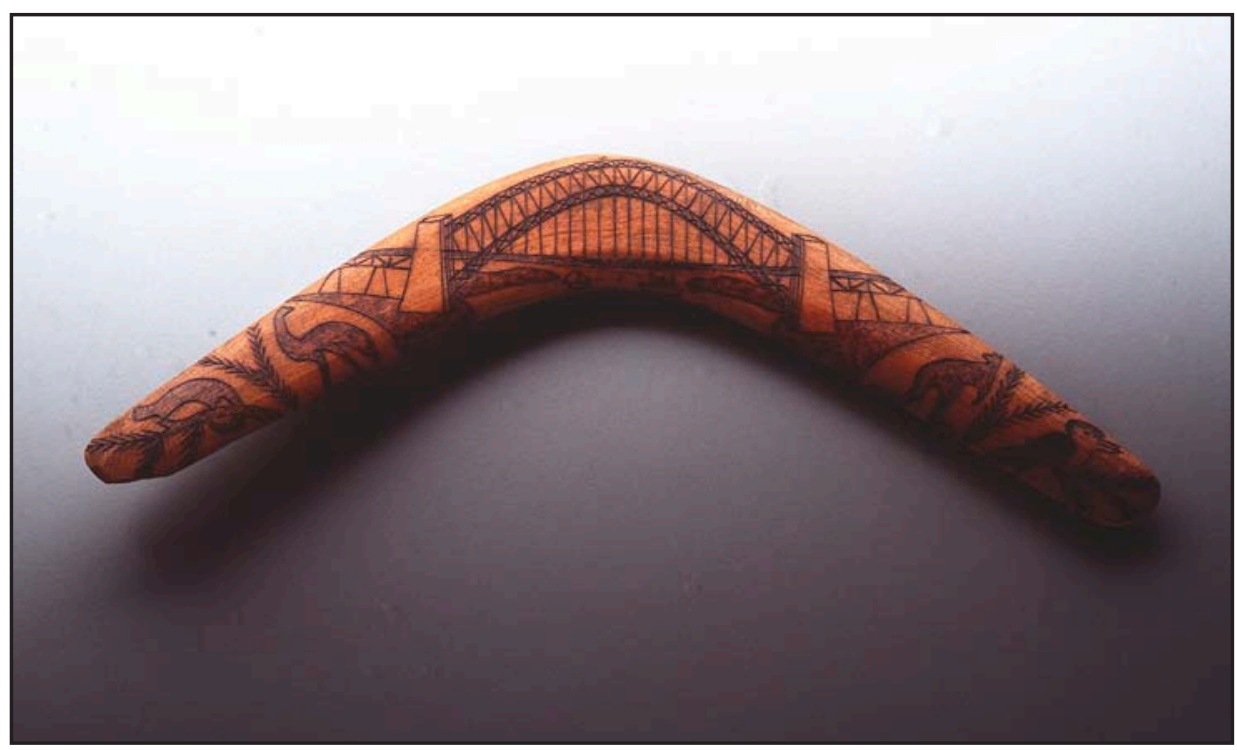

Figure 12.4 Boomerang, La Perouse Aboriginal community, New South Wales, Australia, circa 1935

Source: Powerhouse Museum, Sydney.

\section{Conclusion}

While it is not possible to measure with much precision the amount of income the shell-work trade provided to Aboriginal women, even the briefest of surveys of the markets through which shell-work has circulated over the past 130 or so years reveals that this commodity has been an enduring, if precarious, source of cash. Throughout this long period, Aboriginal women at La Perouse somehow managed to find a market for their handiwork on the city's streets and in the suburbs' houses, in metropolitan missionary exhibitions, in international charity fetes and in the industrial pavilion of local agricultural shows. It seems they had little trouble turning their skills to modifying their wares to cater to a tourist market emerging and expanding in their own backyard at La Perouse. These various markets for the same commodity overlapped. But it was as a souvenir that shell-work continued to be produced from the 1930s until the 1960s and 1970s, as the tourist trade became more important than earlier markets for it. Given this historical context, the recent marketing, production and circulation of Aboriginal women's shell-works-as-artworks appear less like a break with the past and more like a continuation of it. Art galleries, art collectors and art curators have joined the ranks of those who have, over the past 130 or so years, sought to acquire pieces. From the very outset, Aboriginal women produced 
shell-work as a commodity, and that has not changed as it has been taken up by the art world. Throughout this history, practising shell-workers negotiated the various markets available to them, even as the objects they made stubbornly retained something of the quality of a Victorian-era, feminine, decorative craft.

\section{References}

Allas, T. 2006. Esme Timbery. Art Monthly Australia (187) (March): 24-6.

Appadurai, A. 2005 [1986]. Introduction: commodities and the politics of value. In A. Appadurai (ed.), The Social Life of Things: Commodities in cultural perspective, pp. 3-63. Cambridge: Cambridge University Press.

Ardler, G. 1988. My grandmother and her family. In La Perouse: The place, the people and the sea. Canberra: Aboriginal Studies Press.

Barwick, D. E. 1974. And the lubras are ladies now. In F. Gale (ed.), Woman's Role in Aboriginal Society, pp. 54-7. Second edn. Canberra: Australian Institute of Aboriginal Studies.

Brewis, G. 2009. From working parties to social work: middle-class girls' education and social service 1890-1914. History of Education 38 (6): 761-77.

Cochrane, G. 1992. The Crafts Movement in Australia: A history. Sydney: UNSW Press.

Cochrane, P. 2006. Colonial Ambition: Foundations of Australian democracy. Melbourne: Melbourne University Press.

Curthoys, A. 1982. Good Christians and useful workers: Aborigines, church and state in NSW 1870-1833. In What Rough Beast? The state and social order in Australian history, pp. 31-56. Sydney: Allen \& Unwin in association with Australian Society for the Study of Labour History.

Curthoys, A. and Moore, C. 1995. Working for the white people: an historiographic essay on Aboriginal and Torres Strait Islander labour. In A. McGrath and K. Saunders with J. Huggins (eds), Aboriginal Workers, pp. 20-9. Sydney: Australian Society for the Study of Labour.

Finlayson, J. 1990. Tourist art versus fine art. In J. Altman and L. Taylor (eds), Marketing Aboriginal Art in the 1990s, pp. 55-64. Canberra: Aboriginal Studies Press.

Fondas, J. 2002. Sailors' Valentines: Their journey through time. New York: Rizzoli. 
Indigenous Participation in Australian Economies II

Goodall, H. 1996. Invasion to Embassy: Land in Aboriginal politics in New South Wales, 1770-1972. Sydney: Allen \& Unwin.

Graeburn, N. (ed.) 1976. Ethnic and Tourist Arts: Cultural expressions from the fourth world. Berkeley: University of California Press.

Hart, D. 2003. Home sweet home: an artist-collector's passion. In Home Sweet Home: Works from the Peter Fay collection, pp. 9-32. Canberra: National Gallery of Australia.

Isaacs, J. 1987. The Gentle Arts: 200 years of Australian women's domestic and decorative arts. Sydney: Lansdowne.

Karskens, G. 2009. The Colony: A history of early Sydney. Sydney: Allen \& Unwin.

Kleinert, S. 1994. 'Jacky Jacky was a smart young fella': a study of art and Aboriginality in south east Australia 1900-1980. PhD thesis, Australian National University, Canberra.

Kleinert, S. and Neale, M. (eds) 2000. The Oxford Companion to Aboriginal Art and Culture. Melbourne: Oxford University Press.

Logan, J. 1998. Everyday Art: Australian folk art. Canberra: National Gallery of Australia.

Longbottom, M. and Ryan, L. 1986. Oral history interview, 26 November, Powerhouse Museum collection, Sydney.

McKenzie, P. and Stephen, A. 1987. La Perouse: an urban Aboriginal community. In M. Kelly (ed.), Sydney: City of suburbs, pp. 172-91. Kensington, NSW: UNSW Press in association with the Sydney History Group.

Morphy, H. 1991. Ancestral Connections: Art and an Aboriginal system of knowledge. Chicago: University of Chicago Press.

Myers, F. 2002. Painting Culture: The making of an Aboriginal high art. Durham, NC: Duke University Press.

Nash, D. 2010. From shell work to shell art: Koori women creating knowledge and value on the South Coast of NSW. craft + design enquiry 2 [not paginated].

New South Wales Legislative Council 1883. Report of the Protector of Aborigines, to 31 December 1882, Senior-Constable Byrne to Protector of Aborigines, 17 January 1883. Journal of the New South Wales Legislative Council 34, part 2.

Nugent, M. 2005. Botany Bay: Where histories meet. Sydney: Allen \& Unwin. 
Pakula, K. 2007. Shell bridge: the gap between kitsch and art. Sydney Morning Herald, 6 April.

Parliament of New South Wales 2005. Parliament of New South Wales Indigenous Art Prize 2005. Campbelltown, NSW: Campbelltown Arts Centre.

Phillips, R. B. 1995. Why not tourist art? Significant silences in Native American museum representations. In G. Prakash (ed.), After Colonialism: Imperial histories and postcolonial displacements, pp. 98-125. Princeton, NJ: Princeton University Press.

Phillips, R. B. 1998. Trading Identities: The souvenir in Native North American art from the northeast, 1700-1900. Seattle and Montreal: University of Washington Press/McGill-Queen's University Press.

Phillips, R. B. and Steiner, C. B. (eds) 1999. Art, authenticity and the baggage of cultural encounter. In Unpacking Culture: Art and commodity in colonial and postcolonial worlds, pp. 3-19. Berkeley: University of California Press.

Ryan, L. 2003. Shellwork: from bridges to maps. In Steppin' Out and Speakin' Up, pp. 11-21. Millers Point, NSW: Older Women's Network New South Wales.

Stephen, A. 1995. Jane and Olive Simms. Dictionary of Australian Artists Online. Viewed 22 December 2009, <http://www.daao.org.au/bio/emma-timbery/>

Telfer, E. J. 1939. Amongst Australian Aborigines: Forty years of mission workthe story of the United Aborigines Mission. Melbourne: Fraser and Morphett.

Toller, J. 1969. The Regency and Victorian Crafts, or The Genteel Female-her arts and pursuits. London: Ward Lock Limited.

Toy, A. 1988. Hearth and Home: Women's decorative arts and crafts 1800-1930. Sydney: Historic Houses Trust of New South Wales.

Vanni, I. 2000. Bridging the gap: the production of tourist objects at La Perouse. In S. Kleinert and M. Neale (eds), The Oxford Companion to Aboriginal Art and Culture, pp. 400-2. Melbourne: Oxford University Press.

West, M. 2007. Strings through the heart. In ReCoil: Change and exchange in coiled fibre art, pp. 13-27. Darwin: Artback Northern Territory Arts Touring. 